\title{
THE EFFECT OF HOOKWORM INFECTION AND URINARY SCHISTOSOMIASIS ON BLOOD HEMOGLOBIN CONCENTRATION OF SCHOOLCHILDREN LIVING IN NORTHERN MOZAMBIQUE
}

Verónica CASMO(1), Gerito AUGUSTO(1), Rassul NALA(1), Acácio SABONETE(1) \& Filipe Anibal CARVALHO-COSTA(2)

\begin{abstract}
SUMMARY
This study aims to assess the association between schistosomiasis and hookworm infection with hemoglobin levels of schoolchildren in northern Mozambique. Through a cross-sectional survey, 1,015 children from five to 12 years old in the provinces of Nampula, Cabo Delgado and Niassa were studied. Hookworm infection and urinary schistosomiasis were diagnosed, through Ritchie and filtration methods, with a prevalence of $31.3 \%$ and $59.1 \%$, respectively. Hemoglobin levels were obtained with a portable photometer $\left(\right.$ Hemocue $\left.^{\circledast}\right)$. The average hemoglobin concentration was $10.8 \pm 1.42 \mathrm{~g} / \mathrm{dL}$, and $62.1 \%$ of the children presented levels below $11.5 \mathrm{~g} / \mathrm{dL}$, of which $11.8 \%$ of the total number of children had hemoglobin levels below $9 \mathrm{~g} / \mathrm{dL}$. A multiple linear regression analysis demonstrated negative interactions between hemoglobin levels and ancylostomiasis, this being restricted to the province of Cabo Delgado $(\beta=-0.55 ; p<0.001)$ where an independent interaction between hemoglobin levels and urinary schistosomiasis was also observed $(\beta=-0.35 ; p=0.016)$. The logistical regression model indicated that hookworm infection represents a predictor of mild $(\mathrm{OR}=1.87$; $95 \% \mathrm{CI}=1.17-3.00)$ and moderate/severe anemia $(\mathrm{OR}=2.71 ; 95 \% \mathrm{CI}=1.50-4.89)$. We concluded that, in the province of Cabo Delgado, hookworm and Schistosoma haematobium infections negatively influence hemoglobin levels in schoolchildren. Periodical deworming should be considered in the region. Health education and improvements in sanitary infrastructure could achieve long-term and sustainable reductions in soil-transmitted helminthiases and schistosomiasis prevalence rates.
\end{abstract}

KEYWORDS: Hookworms; Schistosoma haematobium; Anemia; Hemoglobin; Mozambique.

\section{INTRODUCTION}

Urinary schistosomiasis is a major health concern in sub-Saharan Africa $^{22}$, while hookworm disease afflicts about 740 million people in the developing world ${ }^{29}$. Control initiatives for schistosomiasis and soil-transmitted helminth infections have been implemented in many sub-Saharan African countries with technical and financial support, in part, from the Schistosomiasis Control Initiative, a charitable institution ${ }^{9}$.

Helminthic infections, as well as poly-parasitism, are associated with anemia ${ }^{7}$, protein-energy malnutrition ${ }^{12}$ and cognitive deficits ${ }^{24}$. In this context, it has been demonstrated that hookworm infection, due to its pathogenic mechanisms, is the main intestinal parasitosis related to iron deficiency anemia ${ }^{4}$.

Hookworm species infecting humans in the African continent include Ancylostoma duodenale and Necator americanus, whose eggs are indistinguishable through light microscopy. Adult worms attach themselves to the intestinal mucosa which results in blood loss from the host, which may be significant in high parasitic burdens, and aggravated by iron-deficient diets based on starch intake, other infectious diseases like malaria and sickle-cell anemia which have a high prevalence in Africa.

Schistosomiasis morbidity is mainly associated with egg obstruction and fibrosis in various organs, depending upon the species of schistosomes. In addition, urinary schistosomiasis, caused by Schistosoma haematobium (a species that most often inhabits the venous plexus of the bladder) is a leading cause of hematuria. Blood loss through the urinary tract can be formidable and associated with anemia. Again, high intensity of infection has been an important factor that has contributed to morbidity in children ${ }^{14}$. The control of helminthic infections in children can supposedly be achieved by strategically reducing the potential for worm burden and transmission via periodical mass administrations of a single-dose of orally-active antihelminthic drugs targeting $75-100 \%$ of school-aged children ${ }^{28}$.

In a previous report, we demonstrated that urinary schistosomiasis, hookworm disease and other intestinal parasitic infections are highly prevalent in Mozambican schoolchildren in most provinces of the country ${ }^{1}$. Our survey aims to assess hookworm infection and urinary schistosomiasis associated anemia in schoolchildren living in three provinces of northern Mozambique.

(1) Laboratório de Parasitologia Intestinal e Vesical do Instituto Nacional de Saúde de Moçambique, Av. Eduardo Mondlane 1008, Cidade de Maputo, Moçambique.

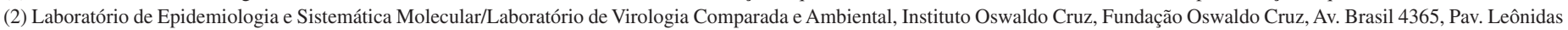
Deane, Sala 308; 21045-900 Rio de Janeiro, RJ, Brazil.

Correspondence to: Filipe Anibal Carvalho-Costa. E-mail: guaratiba@ioc.fiocruz.br 


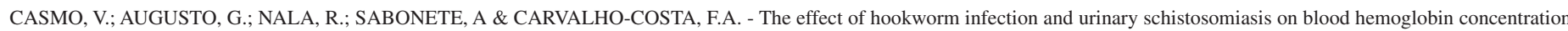
of schoolchildren living in northern Mozambique. Rev. Inst. Med. Trop. Sao Paulo, 56(3): 219-24, 2014.

\section{METHODS}

Setting. The study was carried out in the provinces of Nampula, Cabo Delgado and Niassa, situated in northern Mozambique. Nampula has 3,985,285 habitants distributed among 18 districts and five municipalities, Cabo Delgado has 1,650,270 inhabitants distributed among 16 districts and three municipalities and Niassa has a population of 1,027,037 spread among 15 districts and three municipalities. More information about the characteristics of these provinces has been presented in a previous report ${ }^{1}$.

Strategy for children recruitment and sampling. This study was carried out in a subgroup of the population analyzed by AUGUSTO et al. 2009 from August 2005 to June 2007 by the Schistosomiasis and SoilTransmitted Helminthiases Laboratory of the National Institute of Health of the Ministry of Health, Mozambique. In the studied areas, each district or municipality is divided into small areas called Pedagogical Influence Zones (PIZ), each containing an average of eight schools. One school from each PIZ was randomly selected for this study from which one class from each grade was included. The sampling was intended to cover the whole province as well as urban and rural zones including children belonging to families with distinct incomes. The research team remained in each of the districts and municipalities for two days, carrying out hemoglobin measurements, gathering demographic data and collecting feces and urine samples. In Nampula, children living in the districts/municipalities of Ilha de Moçambique, Malema, Meconta, Mecubúri, Mogovolas, Mongicual, Murrupula, Nacala Porto, Nacala-a-Velha and Nacaroa were recruited. In Cabo Delgado, children in this cross-sectional survey attended schools in the districts/municipalities of Macomia, Mecufi, Meluco, Mueda, Muindumbe, Namuno, Nangade, Palma, Chiure, Quissanga, Pemba, Mocimboa da Praia and Montepuez. In the province of Niassa the children lived in the districts/municipalities of Cidade de Lichinga, Cuamba, Distrito de Lichinga, Lago, Mandimba, Marrupa, Maúa, Mecanhelas, Mecula, Meterica, Muembe, Ngauma, Nipepe and Sanga.

Collection and processing of stool and urine samples. The children's parents were encouraged to return the fecal and urine samples in previously provided wide-topped polythene identified bottles to members of the research team. Urine samples were collected between 10:00AM and 2:00PM. Stool and urine examinations were conducted in each district by trained members of the research team on samples from 1,015 schoolchildren aged five to 12 years-old. A single stool specimen was taken from each child, the Ritchie technique was applied in order to detect hookworm eggs. Briefly, gauze-filtered stool suspensions were centrifuged and sediments re-suspended in $5 \mathrm{~mL}$ of water, shaken and centrifuged again. Sediments were then re-suspended in $10 \%$ formalin and $3 \mathrm{~mL}$ of ether was added to the suspensions. Tubes were shaken and centrifuged again and the sediment was examined through light microscopy. Furthermore, one urine sample was obtained from each subject to diagnose $S$. haematobium infection using the filtration method and light microscopy $(10 \mathrm{~mL}$ of urine was passed through a nylon filter [4 $\mu \mathrm{m}$ pore size] and the eggs counted under light microscopy). S. haematobium infection intensity was measured according to the number of eggs per $10 \mathrm{~mL}$ of urine. S. haematobium worm burdens were classified into light (1-49 eggs/10 mL of urine) or heavy ( $\geq 50$ eggs/10 $\mathrm{mL}$ of urine $)^{18}$.

Hemoglobin measurements. Blood hemoglobin concentration levels were determined from finger prick blood samples with a Hemocue
Photometer (HemoCue AB, Ängelholm, Sweden). Anemia was defined by values below $11.5 \mathrm{mg} / \mathrm{dL}^{31}$. Severe anemia was designated for hemoglobin levels $<9 \mathrm{mg} / \mathrm{dL}$.

Statistical analyses. Multiple linear regression analysis was employed to investigate the association between hemoglobin levels and the presence of hookworm infection or urinary schistosomiasis maintaining age and gender in the model. In addition, the interaction between anemia/severe anemia and the parasitoses was assessed through logistic regression analysis. We present odds ratios (ORs) and 95\% confidence intervals (CIs). All analyses were done with the statistical software SPSS version 15.0 (SPSS, Inc., Chicago, IL).

\section{RESULTS}

Hookworm disease and urinary schistosomiasis presented prevalence rates of $31.3 \%$ and $59.1 \%$, respectively, and the rate of co-infection with both parasites was $12.7 \%$. Prevalence rates according to gender, age group and province are in Table 1. Hookworms infection was significantly lower in Niassa, and urinary schistosomiasis was less frequent in Cabo Delgado. Detection rates of enteric protozoa were as follows: $3.3 \%$ Giardia duodenalis $(\mathrm{n}=34), 2 \%$ Entamoeba histolytica $(\mathrm{n}=20), 1.1 \%$ Iodamoeba bütschlii $(\mathrm{n}=11), 1.3 \%$ Endolimax nana $(\mathrm{n}=13)$ and $34.9 \%$ Entamoeba coli $(\mathrm{n}=354)$ (not shown).

Hemoglobin concentration averages were lower in Cabo Delgado and among children from five to six years old. Also, the anemia prevalence rate was significantly higher in Cabo Delgado (Table 1).

As presented in Table 2, a multivariate analysis through multiple linear regression demonstrated independent negative associations between hemoglobin levels and both hookworm $(\beta=-0.55 ; p<0.001)$ and $S$. haematobium ( $\beta=-0.35 ; p=0.016)$, after considering age and gender. These findings were only in the province of Cabo Delgado. Additionally, as presented in Tables 3 and 4, the logistic regression model suggests that, in Cabo Delgado, hookworm disease represents a risk for the development of mild $(\mathrm{OR}=1.87 ; 95 \% \mathrm{CI}=1.17-3.00)$ and moderate/ severe anemia based on hemoglobin level $<9 \mathrm{mg} / \mathrm{dL}(\mathrm{OR}=2.71 ; 95 \%$ $\mathrm{CI}=1.50-4.89)$.

\section{DISCUSSION}

Results from this study suggest that hookworm and S. haematobium infections are independently associated with lower hemoglobin levels among schoolchildren living in the Cabo Delgado province, northern Mozambique. Furthermore, hookworm disease proved to be a predictor of both mild and severe anemia in this province but not in Nampula and Niassa provinces. The main limitation of this study, however, is the fact that almost $25 \%$ of the children in the studied provinces do not attend schools. Therefore, prevalence rates and the interaction of hookworm disease and schistosomiasis with hemoglobin levels in this subgroup could not be assessed. As observed in many cross-sectional surveys aiming to evaluate the relationships between helminthic infections with anemia and other nutritional parameters, cumulative effects of previously resolved infections could not be evaluated.

The main finding of this survey is the distinct influence that the studied helminth infections exerted over the hemoglobin levels in 


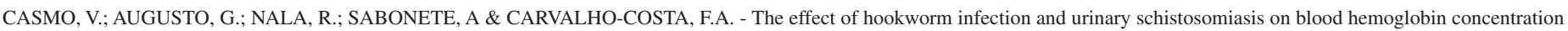
of schoolchildren living in northern Mozambique. Rev. Inst. Med. Trop. Sao Paulo, 56(3): 219-24, 2014.

Table 1

Prevalence of hookworm infection, urinary schistosomiasis, anemia and severe anemia and mean blood hemoglobin levels by gender, age group and province in Northern Mozambique

\begin{tabular}{|c|c|c|c|c|c|c|}
\hline Characteristic & $\begin{array}{l}\text { Hookworm } \\
\text { infection, } \\
\mathrm{n}(\%)\end{array}$ & $\begin{array}{c}\text { Urinary } \\
\text { schistosomiasis, } \\
\text { n }(\%)\end{array}$ & $\begin{array}{c}\text { Hookworm + } \\
\text { Schistosoma } \\
\text { haematobium co- } \\
\text { infection }\end{array}$ & $\begin{array}{c}\text { Anemia, } \\
\mathrm{n}(\%)\end{array}$ & $\begin{array}{c}\text { Moderate/Severe } \\
\text { anemia, } \\
\text { n }(\%)\end{array}$ & $\begin{array}{c}\text { Mean hemoglobin } \\
\text { level } \pm \text { standard } \\
\text { deviation }\end{array}$ \\
\hline \multicolumn{7}{|l|}{ Gender } \\
\hline Male & $145(29.4)$ & $287(58.2)$ & $63(12.8)$ & $236(47.9)$ & $62(12.6)$ & $10.88 \pm 1.52$ \\
\hline Female & $173(33.1)$ & $313(60)$ & $66(12.6)$ & $245(46.9)$ & $58(11.1)$ & $10.91 \pm 1.53$ \\
\hline \multicolumn{7}{|l|}{ Age groups, years } \\
\hline $5-6$ & $1(5.9)$ & $10(58.8)$ & $1(5.9)$ & $12(70.6)$ & $5(29.4)$ & $10.11 \pm 1.26$ \\
\hline $7-8$ & $90(32.5)$ & $163(58.8)$ & $52(18.8)$ & $150(54.2)$ & $39(14.1)$ & $10.72 \pm 1.54$ \\
\hline $9-10$ & $140(33.3)$ & $242(57.6)$ & $61(14.5)$ & $182(43.3)$ & $52(12.4)$ & $10.93 \pm 1.52$ \\
\hline $11-12$ & 87 (28.9) & $185(61.5)$ & $15(5)$ & $137(45.5)$ & $24(8)$ & $11.05 \pm 1.49$ \\
\hline \multicolumn{7}{|l|}{ Province } \\
\hline Nampula & $110(33.6)$ & $201(61.5)$ & $73(22.3)$ & $147(45)$ & $41(12.5)$ & $10.98 \pm 1.63$ \\
\hline Cabo Delgado & $139(35)$ & $207(52.1)$ & $56(14.1)$ & $214(53.9)$ & $54(13.6)$ & $10.69 \pm 1.47$ \\
\hline Niassa & $69(23.7)$ & $192(66)$ & $0(0)$ & $120(41.2)$ & $25(8.6)$ & $11.07 \pm 1.42$ \\
\hline
\end{tabular}

Table 2

Multiple linear regression analysis of blood hemoglobin concentration by Schistosoma haematobium and hookworm infections, age and sex of schoolchildren in three provinces in northern Mozambique

\begin{tabular}{lccc}
\hline & $\beta$ & Standard-error & $p$-value \\
\hline Total population & & & \\
Urinary schistosomiasis & -0.07 & 0.097 & 0.469 \\
Hookworm infection & -0.334 & 0.102 & 0.001 \\
Age & 0.107 & 0.03 & $<0.001$ \\
Sex & 0.034 & 0.095 & 0.722 \\
Nampula & & & \\
Urinary schistosomiasis & 0.192 & 0.185 & 0.299 \\
Hookworm infection & -0.163 & 0.191 & 0.392 \\
Age & 0.164 & 0.057 & 0.004 \\
Sex & -0.008 & 0.18 & 0.963 \\
Cabo Delgado & & & \\
Urinary schistosomiasis & -0.351 & 0.145 & 0.016 \\
Hookworm infection & -0.554 & 0.152 & $<0.001$ \\
Age & 0.056 & 0.045 & 0.210 \\
Sex & 0.063 & 0.147 & 0.670 \\
Niassa & & & \\
Urinary schistosomiasis & -0.136 & 0.18 & 0.451 \\
Hookworm infection & -0.086 & 0.201 & 0.667 \\
Age & 0.094 & 0.055 & 0.088 \\
Sex & 0.047 & 0.169 & 0.778 \\
\hline
\end{tabular}

\section{Table 3}

Logistic regression analysis assessing the relationships between urinary schistosomiasis and hookworm infection and anemia defined by blood hemoglobin concentration below $11.5 \mathrm{~g} / \mathrm{dL}$, controlling for age and sex

\begin{tabular}{lccc}
\hline & Odds ratio & $\begin{array}{c}95 \% \text { Confidence } \\
\text { Interval }\end{array}$ & $p$-value \\
\hline Total population & & & \\
Urinary schistosomiasis & 1.0576 & $0.8155-1.3714$ & 0.673 \\
Hookworm infection & 1.3793 & $1.0419-1.8258$ & $0.024 *$ \\
Age & 0.9072 & $0.8374-0.9827$ & $0.017 *$ \\
Sex & 1.1362 & $0.8802-1.4668$ & 0.326 \\
Nampula & & & \\
Urinary schistosomiasis & 0.8959 & $0.5633-1.4249$ & 0.642 \\
Hookworm infection & 1.0694 & $0.6621-1.7273$ & 0.783 \\
Age & 0.8777 & $0.7607-1.0128$ & 0.074 \\
Sex & 1.6507 & $1.0518-2.5907$ & $0.029 *$ \\
Cabo Delgado & & & \\
Urinary schistosomiasis & 1.4522 & $0.9451-2.2313$ & 0.088 \\
Hookworm infection & 1.8731 & $1.1689-3.0015$ & $0.009 *$ \\
Age & 0.9491 & $0.8314-1.0835$ & 0.439 \\
Sex & 1.0777 & $0.6987-1.6624$ & 0.734 \\
Niassa & & & \\
Urinary schistosomiasis & 1.1021 & $0.6697-1.8136$ & 0.702 \\
Hookworm infection & 1.0754 & $0.616-1.8772$ & 0.798 \\
Age & 0.9203 & $0.7895-1.0727$ & 0.287 \\
Sex & 0.8367 & $0.5243-1.3351$ & 0.454 \\
\hline * Statistically significant values. & & & \\
& & &
\end{tabular}




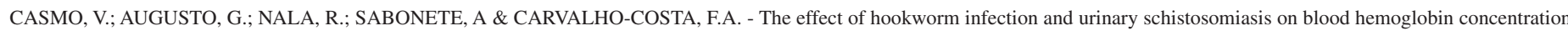
of schoolchildren living in northern Mozambique. Rev. Inst. Med. Trop. Sao Paulo, 56(3): 219-24, 2014.

Table 4

Logistic regression analysis assessing the relationships between urinary schistosomiasis and hookworm infection and moderate/severe anemia defined by blood hemoglobin concentration below $9 \mathrm{~g} / \mathrm{dL}$, controlling for age and sex

\begin{tabular}{lccc}
\hline & Odds ratio & $\begin{array}{c}95 \% \text { Confidence } \\
\text { Interval }\end{array}$ & $p$-value \\
\hline Total population & & & \\
Urinary schistosomiasis & 1.2079 & $0.8105-1.8003$ & 0.353 \\
Hookworm infection & 1.7376 & $1.1729-2.574$ & $0.005^{*}$ \\
Age & 0.8295 & $0.7352-0.9359$ & $0.002^{*}$ \\
Sex & 0.8604 & $0.5853-1.2648$ & 0.444 \\
Nampula & & & \\
Urinary schistosomiasis & 0.9697 & $0.4929-1.9078$ & 0.928 \\
Hookworm infection & 1.2952 & $0.6559-2.5579$ & 0.456 \\
Age & 0.8761 & $0.7074-1.085$ & 0.225 \\
Sex & 0.9041 & $0.4671-1.7502$ & 0.764 \\
Cabo Delgado & & & \\
Urinary schistosomiasis & 1.3679 & $0.7539-2.482$ & 0.302 \\
Hookworm infection & 2.7448 & $1.522-4.9501$ & $<0.001^{*}$ \\
Age & 0.8471 & $0.7068-1.0152$ & $0.072 *$ \\
Sex & 0.7003 & $0.3838-1.2777$ & 0.245 \\
Niassa & & & \\
Urinary schistosomiasis & 1.9013 & $0.7169-5.0422$ & 0.196 \\
Hookworm infection & 0.7629 & $0.2689-2.1642$ & 0.610 \\
Age & 0.7886 & $0.6027-1.0318$ & 0.083 \\
Sex & 1.2445 & $0.5319-2.8912$ & 0.618 \\
\hline Staticaly signicant valws & & &
\end{tabular}

* Statistically significant values.

different provinces. Unfortunately, we could not perform Kato-Katz smears in order to better characterize worm burdens, which would have been extremely elucidating. In this context, we believe that the average intensity of hookworm infection in Cabo Delgado must be higher than in Nampula and Niassa. In addition, we observed that the prevalence rate of hookworm infection was higher in Cabo Delgado, and significantly lower in Niassa.

According to the Multiple Indicator Cluster Survey (MICS) carried out in Mozambique in 2008, Cabo Delgado had a worse sanitary background than either Nampula or Niassa ${ }^{11}$. The proportion of families with access to improved sanitary conditions facilitating solid organic waste disposal (i.e. improved latrines) was 5.6\% in Cabo Delgado, $15.2 \%$ in Nampula and $15.4 \%$ in Niassa. In Cabo Delgado, $4.3 \%$ of the families defecate on the beach, $25.3 \%$ in bushes and $64.7 \%$ have rudimentary latrines unable to contain solid excrement. The prevalence of hookworm infection was significantly lower in the Niassa province. According to the MICS, Niassa is the province where there is the lowest proportion of open sky defecation (i.e. defecation made directly into the soil, leaving the feces exposed to the environment ${ }^{11}$. Additionally, Niassa is a province where the population is more dispersed, probably making hookworm transmission more difficult. Furthermore, in Cabo Delgado only $29.9 \%$ of the families have access to improved sources of drinking water, this proportion reaching $43.1 \%$ in Nampula and $44.1 \%$ in Niassa. Cabo Delgado also presents the highest child mortality rate in northern Mozambique (180 / 1,000 live births), this rate is 140 / 1,000 in Nampula and 123/1,000 in Niassa. Cabo Delgado is also plagued with the highest proportion of chronic malnutrition (stunting) among children under five years old, $56 \%$, defined by height-for-age z-scores below - 2 vs. $51 \%$ in Nampula and $45 \%$ in Niassa ${ }^{11}$. Taking into account all this data serves to highlight atrocious sanitary scenario in Cabo Delgado. In this context, a higher level of environmental contamination with the infective stages of hookworms (i.e. larvae that penetrate the skin) and, consequently, higher parasite burdens should be expected in the studied districts of the Cabo Delgado province, parasite burden being intrinsically linked to continuous re-infections.

The interactions between hookworm infections and anemia were demonstrated in primary schoolchildren living in India ${ }^{20}$, Zimbabwe ${ }^{17}$ and Tanzania ${ }^{26}$. Nevertheless, some surveys that attempted to characterize the relationship between hookworm disease and hemoglobin levels failed to find a conclusive association between these variables. In this context, studies performed in distinct countries included preschool and schoolchildren in Zanzibar ${ }^{13,15}$, preschoolchildren in the Brazilian Amazon $^{5}$ and South Africa ${ }^{8}$ and pregnant women in Kenya ${ }^{28}$. Factors leading to such incongruent results are probably distinct intensities (often not assessed through quantitative stool examinations, e.g. Kato-Katz smears) of helminthic infections in different studies and potential biases such as distinct socio-economic, dietary, demographic, epidemiologic and sanitary circumstances. Also, studies assessing the impact of antihelminthic administration on anemia prevalence and hemoglobin levels reveal conflicting results. It has been demonstrated that anti-helminthic drugs significantly decrease the burden of helminth infections and reduce anemia prevalence among schoolchildren in the Ivory Coast ${ }^{22}$. However, this effect was not observed in pregnant women in Uganda, probably due to low hookworm burdens ${ }^{19}$.

Taking everything into consideration, it has been proposed that the influence of soil-transmitted helminthiases on nutritional deficits, such as iron imbalance, should be taken into account in the context of interrelated determinants. The main factors are poor dietary intake and infectious diseases, which are affected by family access to good water, sanitation and adequate health services ${ }^{27}$.

In the provinces of northern Mozambique prevalence rates of anemia were also very high (above 60\%) among non-parasitized children who, also, presented an average hemoglobin level below $11.5 \mathrm{mg} / \mathrm{dL}$. This demonstrates that other factors besides helminthic infections strongly contribute to anemia in the studied area. Malaria and inadequate iron intake due to a predominantly starch-based diet are probably other determinants of anemia in Mozambican children living in the province of Cabo Delgado. In Niassa and Nampula, these two considerations should be viewed as the main causes of anemia, since no relationship between the studied parasitoses and hemoglobin levels was established. The affliction of malaria and its possible effects on hemoglobin levels of children in northern Mozambique can be estimated indirectly. During a demographic survey in $2008^{11}, 26.7 \%$ of the children in Nampula, $20.1 \%$ in Cabo Delgado and $13.9 \%$ in Niassa presented a fever during the 14 days before the survey, of which $57.6 \%$ of the children in Nampula, 47.4\% in Cabo Delgado and $26.5 \%$ in Niassa were treated with antimalarial drugs. This demonstrated that malaria reaches hyperendemic 


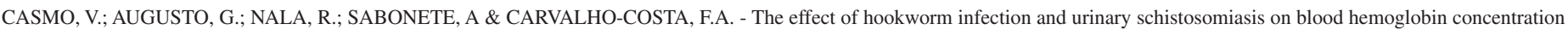
of schoolchildren living in northern Mozambique. Rev. Inst. Med. Trop. Sao Paulo, 56(3): 219-24, 2014.

levels in the studied area and should be viewed as a determinant of the high prevalence of anemia as has been extensively demonstrated in other regions in Africa ${ }^{3,16}$. In addition, the effect of malaria and enteric helminth infections on anemia prevalence among schoolchildren was exhibited in Ethiopia ${ }^{6}$.

The interaction between urinary schistosomiasis and iron deficiency was reported in Kenya ${ }^{24}$ and Niger $^{21}$. However, an extensive study performed in Cameroon did not demonstrate an association between $S$. haematobium and anemia in primary schoolchildren, probably due to low parasitic loads ${ }^{2}$.

Soil-transmitted helminth infections and schistosomiasis associated morbidity mitigation focusing on worm burden control must be considered as a cost effective short-term initiative that can be linked to vaccination campaigns. In many developing countries, periodical mass treatments are extensively applied ${ }^{10}$. In rural Mozambique, vaccine coverage reaches $83 \%$ for tuberculosis (BCG), $71 \%$ for the DPT3 vaccine (diphtheria-pertussis-tetanus) and $70 \%$ for the oral poliomyelitis vaccine $^{11}$. These rates could allow for an inference on the coverage of deworming campaigns. Massive deworming must, however, be accompanied by projects focusing on health education and improvements in sanitary infrastructure in order to achieve long term and sustainable reductions in soil-transmitted helminthiases as well as schistosomiasis prevalence rates. Very distinct proportions of families with access to safe solid waste disposal are evident between urban $(47 \%)$ and rural $(6 \%)$ zones in Mozambique ${ }^{11}$.

We conclude that hookworm infection and urinary schistosomiasis are major public health concerns in the studied area. Periodical deworming should be performed on a strictly regular basis in conjunction with the vaccination campaigns.

\section{RESUMO}

\section{Infecções por ancilostomídeos e Schistosoma haematobium e sua correlação com a concentração sanguínea de hemoglobina em crianças moçambicanas}

Este estudo tem como objetivo avaliar a relação entre a ancilostomíase e a esquistossomíase urinária com as concentrações sanguíneas de hemoglobina em crianças escolares no norte de Moçambique. Em estudo transversal, 1.015 crianças com idade entre cinco e 12 anos foram incluídas, nas Províncias de Nampula, Cabo Delgado e Niassa. A ancilostomíase e a esquistossomíase urinária foram diagnosticadas através das técnicas de Ritchie e de filtração da urina, respectivamente; prevalências de $31,3 \%$ e $59,1 \%$ foram observadas. As concentrações sanguíneas de hemoglobina foram obtidas com um fotômetro portátil (Hemocue). A concentração média de hemoglobina foi 10,8 $\pm 1.42 \mathrm{~g} / \mathrm{dL}$, $62,1 \%$ das crianças apresentaram concentração abaixo de $11,5 \mathrm{~g} / \mathrm{dL}$ e $11,8 \%$ apresentaram nível abaixo de $9 \mathrm{~g} / \mathrm{dL}$. A regressão linear múltipla demonstrou interações negativas entre os níveis de hemoglobina e i) a infecção por ancilostomídeos $(\beta=-0,55 ; p<0,001)$ e ii) a esquistossomíase urinária $(\beta=-0,35 ; p=0,016)$, ambas associações restritas à Província de Cabo Delgado. Também em Cabo Delgado, o modelo de regressão logística demonstrou que a infecção por ancilostomídeos representa um preditor de anemia leve $(\mathrm{OR}=1,87 ; 95 \% \mathrm{CI}=1,17-3,00)$ e anemia moderada/grave $(\mathrm{OR}=2,71 ; 95 \% \mathrm{CI}=1,50-4,89)$. $\mathrm{O}$ estudo conclui que em Cabo Delgado, Moçambique, as infecções por ancilostomídeos e Schistosoma haematobium estão significativamente associadas a uma menor concentração sanguínea de hemoglobina em crianças em idade escolar. A administração periódica de anti-helmínticos deve ser feita regularmente. Melhorias na infraestrutura sanitária das regiões estudadas são as medidas mais eficazes para controle destas parasitoses.

\section{ACKNOWLEDGEMENTS}

We respectfully dedicate this article to the acclaimed Brazilian parasitologist Professor Luis Rey, former coordinator of the National Institute of Health of Mozambique, leading campaigns to schistosomiasis control in Africa. We thank the children and teachers from PIZs in Niassa, Cabo Delgado and Nampula for their cooperation in this study. We are also grateful to Dr. Joao Fumane (former Director of the National Institute of Health), Dr. Ilesh Jani (Director of the National Institute of Health), Professor Alan Fenwick (Schistosomiasis Control Initiative) and the technicians of the Schistosomiasis and Soil-Transmitted Helminthiases Laboratory (Francisco Matavele, Carlos Muchanga, Inácio Auze, Fernando Chirinzane, and Benedito Muianga) for essential support.

\section{FUNDING}

This study was supported by the Ministry of Health of Mozambique and Schistosomiasis Control Initiative. Part of this study comprises the work towards a Master's Degree in Health Sciences in the Oswaldo Cruz Foundation (Fiocruz) for Verónica Casmo.

\section{CONFLICTS OF INTEREST}

None declared.

\section{ETHICAL APPROVAL}

This study was previously approved by the National Bio-ethics Committee for Health of Mozambique. Informed consent was obtained from parents or legal guardians of all children.

\section{REFERENCES}

1. Augusto G, Nalá R, Casmo V, Sabonete A, Mapaco L, Monteiro J. Geographic distribution and prevalence of schistosomiasis and soil-transmitted helminths among schoolchildren in Mozambique. Am J Trop Med Hyg. 2009;81:799-803.

2. Befidi-Mengue RN, Ratard RC, Beltran G, D'alessandro A, Rice J, Befidi-Mengue R, et al. Impact of Schistosoma haematobium infection and of Praziquantel treatment on anaemia of primary school children in Bertoua, Cameroon. J Trop Med Hyg. 1993;96:225-30

3. Boele van Hensbroek M, Calis JC, Phiri KS, Vet R, Munthali F, Kraaijenhagen R, et al. Pathophysiological mechanisms of severe anaemia in Malawian children. PLoS One. 2010;5:e12589

4. Bungiro R, Cappello M. Hookworm infection: new developments and prospects for control. Curr Opin Infect Dis. 2004;17:421-6.

5. Carvalho-Costa FA, Gonçalves AQ, Lassance SL, Silva Neto LM, Salmazo CA, Bóia MN. Giardia lamblia and other intestinal parasitic infections and their relationships with nutritional status in children in Brazilian Amazon. Rev Inst Med Trop Sao Paulo. 2007;49:147-53. 
CASMO, V.; AUGUSTO, G.; NALA, R.; SABONETE, A \& CARVALHO-COSTA, F.A. - The effect of hookworm infection and urinary schistosomiasis on blood hemoglobin concentration of schoolchildren living in northern Mozambique. Rev. Inst. Med. Trop. Sao Paulo, 56(3): 219-24, 2014.

6. Degarege A, Animut A, Legesse M, Erko B. Malaria and helminth co-infections in outpatients of Alaba Kulito Health Center, southern Ethiopia: a cross sectional study. BMC Res Notes. 2010;3:143.

7. Dreyfuss ML, Stoltzfus RJ, Shrestha JB, Pradhan EK, LeClerq SC, Khatry SK, et al. Hookworms, malaria and vitamin A deficiency contribute to anemia and iron deficiency among pregnant women in the plains of Nepal. J Nutr. 2000;130:2527-36.

8. Heckman J, Samie A, Bessong P, Ntsieni M, Hamandi H, Kohler M, et al. Anaemia among clinically well under-fives attending a community health centre in Venda, Limpopo Province. S Afr Med J. 2010;100:445-8

9. Hotez P, Raff S, Fenwick A, Richards F Jr, Molyneux DH. Recent progress in integrated neglected tropical disease control. Trends Parasitol. 2007;23:511-4.

10. Hotez PJ, Brindley PJ, Bethony JM, King CH, Pearce EJ, Jacobson J. Helminth infections: the great neglected tropical diseases. J Clin Invest. 2008;118:1311-21.

11. Instituto Nacional de Estatística. Moçambique. Inquérito sobre indicadores múltiplos 2008. Maputo: Instituto Nacional de Estatística; 2008.

12. Jardim-Botelho A, Brooker S, Geiger SM, Fleming F, Souza Lopes AC, Diemert DJ, et al. Age patterns in undernutrition and helminth infection in a rural area of Brazil: associations with ascariasis and hookworm. Trop Med Int Health. 2008;13:458-67.

13. Knopp S, Mohammed KA, Stothard JR, Khamis IS, Rollinson D, Marti H, et al. Patterns and risk factors of helminthiasis and anemia in a rural and a peri-urban community in Zanzibar, in the context of helminth control programs. PLoS Negl Trop Dis. 2010;4:e681.

14. Koukounari A, Gabrielli AF, Toure S, Bosque-Oliva E, Zhang Y, Sellin B, et al. Schistosoma haematobium infection and morbidity before and after large-scale administration of praziquantel in Burkina Faso. J Infect Dis. 2007;196:659-69.

15. Kung'u JK, Goodman D, Haji HJ, Ramsan M, Wright VJ, Bickle QD, et al. Early helminth infections are inversely related to anemia, malnutrition, and malaria and are not associated with inflammation in 6- to 23-month-old Zanzibari children. Am J Trop Med Hyg. 2009;81:1062-70.

16. Maina RN, Walsh D, Gaddy C, Hongo G, Waitumbi J, Otieno L, et al. Impact of Plasmodium falciparum infection on haematological parameters in children living in Western Kenya. Malar J. 2010;9(Suppl 3):S3-4.

17. Midzi N, Mtapuri-Zinyowera S, Mapingure MP, Sangweme D, Chirehwa MT, Brouwer $\mathrm{KC}$, et al. Consequences of polyparasitism on anaemia among primary school children in Zimbabwe. Acta Trop. 2010;115:103-11.

18. Montresor A, Crompton DW, Hall A, Bundy DA, Savioli L. Guidelines for the evaluation of soil-transmitted helminthiasis and schistosomiasis at community level: a guide for managers of control programmes. Geneva: World Health Organization; 1998. [cited 2013 May 13]. Available from: http://apps.who.int/iris/handle/10665/63821
19. Ndibazza J, Muhangi L, Akishule D, Kiggundu M, Ameke C, Oweka J, et al. Effects of deworming during pregnancy on maternal and perinatal outcomes in Entebbe, Uganda: a randomized controlled trial. Clin Infect Dis. 2010;50:531-40.

20. Osei A, Houser R, Bulusu S, Joshi T, Hamer D. Nutritional status of primary schoolchildren in Garhwali Himalayan villages of India. Food Nutr Bull. 2010;31:221-33.

21. Prual A, Daouda H, Develoux M, Sellin B, Galan P, Hercberg S. Consequences of Schistosoma haematobium infection on the iron status of schoolchildren in Niger. Am J Trop Med Hyg. 1992;47:291-7.

22. Rohner F, Zimmermann MB, Amon RJ, Vounatsou P, Tschannen AB, N'goran EK, et al. In a randomized controlled trial of iron fortification, anthelmintic treatment, and intermittent preventive treatment of malaria for anemia control in Ivorian children, only anthelmintic treatment shows modest benefit. J Nutr. 2010;140:635-41.

23. Steinmann P, Keiser J, Bos R, Tanner M, Utzinger J. Schistosomiasis and water resources development: systematic review, meta-analysis, and estimates of people at risk. Lancet Infect Dis. 2006;6:411-25.

24. Stephenson LS, Latham MC, Kurz KM, Kinoti SN, Oduori ML, Crompton DW Relationships of Schistosoma haematobium, hookworm and malarial infections and metrifonate treatment to hemoglobin level in Kenyan school children. Am J Trop Med Hyg. 1985;34:519-28.

25. Stephenson LS, Holland CV, Cooper ES. The public health significance of Trichuris trichiura. Parasitology. 2000;121(Suppl):S73-95.

26. Tatala SR, Kihamia CM, Kyungu LH, Svanberg U. Risk factors for anaemia in schoolchildren in Tanga Region, Tanzania. Tanzan J Health Res. 2008;10:189-202.

27. United Nations Children's Fund (UNICEF). The state of the world's children. Oxford: Oxford University Press; 1998.

28. Van Eijk AM, Lindblade KA, Odhiambo F, Peterson E, Rosen DH, Karanja D, et al. Geohelminth infections among pregnant women in rural western Kenya; a crosssectional study. PLoS Negl Trop Dis. 2009;3:e370.

29. World Health Organization (WHO). Prevention and control of schistosomiasis and soiltransmitted helminthiasis: report of a WHO expert committee. Geneva: WHO; 2002. (WHO Technical Report Series; 912)

30. World Health Organization (WHO). Parasitic diseases. [cited 2010 Oct 18]. Available from: http://www.who.int/vaccine_research/diseases/soa_parasitic/en/index $2 . h t m l$

31. World Health Organization (WHO). Prevention and control of iron-deficiency anaemia in women and children: report of the UNICEF/WHO regional consultation, Geneva, Switzerland, 3-5 February 1999. Geneva: UNICEF/WHO; 2001. p. 22-5.

Received: 8 March 2013

Accepted: 17 October 2013 